\section{Postharvest Quality of 'Bing' Cherries Following Preharvest Treatment with Hydrogen Cyanamide, Calcium Ammonium Nitrate, or Gibberellic Acid}

\author{
Murray Clayton and William V. Biasi \\ Department of Pomology, University of California, One Shields Ave., Davis, \\ CA 95616
}

I. Tayfun Agar

Department of Horticulture, University of Çukurova, 01330 Adana, Turkey

Stephen M. Southwick and Elizabeth J. Mitcham ${ }^{1}$
Department of Pomology, University of California, One Shields Ave., Davis,
CA 95616

Additional index words. Prunus avium, $\mathrm{CH}_{2} \mathrm{~N}_{2}, \mathrm{CaNH}_{4} \mathrm{NO}_{3}, \mathrm{GA}_{3}$, maturity indices, physiological damage

\begin{abstract}
During three consecutive years, 'Bing' sweet cherry (Prunus avium L.) trees were treated during dormancy with the dormancy-manipulating compounds, $\mathrm{CH}_{2} \mathrm{~N}_{2}$ or $\mathrm{CaNH}_{4} \mathrm{NO}_{3}$, or were treated with the plant growth regulator $\mathbf{G A}_{3}$ at straw color development. Fruit of a range of maturities, based on skin color, were evaluated for quality following harvest and simulated transit and market storage conditions. At comparable maturities, $\mathrm{CH}_{2} \mathrm{~N}_{2}$ and $\mathrm{GA}_{3}$ fruit were of similar firmness and were consistently firmer than $\mathrm{CaNH}_{4} \mathrm{NO}_{3}$-treated and untreated fruit across years, storage regimes, and maturities. $\mathrm{CaNH}_{4} \mathrm{NO}_{3}$ and untreated fruit were of similar firmness. $\mathrm{CH}_{2} \mathrm{~N}_{2}$-treated cherries were larger than fruit of other treatments, but only marginally with respect to variation in fruit size between years. Contraction of fruit diameter occurred after 3 days storage, but ceased thereafter up to 11 days storage. Soluble solids and titratable acidity varied between years, storage regimes, and maturities. Strong interactions of treatment and year concealed possible treatment effects on these indices. $\mathbf{G A}_{3}$ fruit contained fewer surface pits in one year while $\mathrm{CH}_{2} \mathrm{~N}_{2}$ fruit suffered less shrivel in another. The earlier harvest date for $\mathrm{CH}_{2} \mathrm{~N}_{2}$ fruit often avoided higher field temperatures and the resulting promotion of postharvest shrivel. Pitting and shrivel were more prevalent in stored fruit. Brown stem discoloration developed in storage, occurring most frequently in mature fruit, although methyl bromide-fumigated fruit were particularly susceptible. This disorder was more common in $\mathbf{G A}_{3}$ fruit during years of high incidence. Chemical names used: gibberellic acid $\left(\mathrm{GA}_{3}\right)$; calcium ammonium nitrate $\left(\mathrm{CaNH}_{4} \mathrm{NO}_{3}\right)$; hydrogen cyanamide $\left(\mathrm{CH}_{2} \mathrm{~N}_{2}\right)$.
\end{abstract}

The sweet cherry industry has recently experienced considerable growth in California. The production area of bearing cherry trees (predominantly 'Bing') has increased from $\approx 5000$ ha in 1995 to 7500 ha in 1999 , in part due to the development of new cultivars and expansion of plantings into non-traditional areas. Increased production has emphasized the importance of fruit quality and storage potential to increase consumption and increase market flexibility through short-term storage. Increased commercial utilization of compounds regulating the fruiting habits, growth habits, or both, of cherry trees has generated interest in the effects of these compounds on the postharvest life and quality of the treated fruit.

California growers have applied hydrogen cyanamide $\left(\mathrm{CH}_{2} \mathrm{~N}_{2}\right)$ at late dormancy as a means to control dormancy and budbreak in sweet cherry due to marginal or insufficient

Received for publication 4 Mar. 2002. Accepted for publication 23 June 2002.

${ }^{1}$ To whom reprint requests should be addressed.
$\mathrm{GA}_{3}$, SSC and fruit size increased with higher fruit firmness (Facteau, 1982; Facteau et al., 1985), while surface pitting in 'Lambert' decreased following cold storage (Facteau, 1982). In contrast, Looney and Lidster (1980) found no effects at harvest on fruit weight or SSC of 'Lambert' that had been treated with $15 \mu \mathrm{L} \cdot \mathrm{L}^{-1}$ of $\mathrm{GA}_{3}$, but did report increased fruit firmness. They observed no treatment effects on 'Van' for fruit weight, SSC, and firmness. However, the authors stated that the $\mathrm{GA}_{3}$ treatment reduced surface pitting in cold-stored 'Van' that were previously subjected to a postharvest bruising treatment, but reported no effects of $\mathrm{GA}_{3}$ on pitting in 'Lambert' cherries.

Uncertainty persists concerning the effects of $\mathrm{GA}_{3}$ on SSC, TA, size, and surface pitting of cherries, while evidence indicates consistently enhanced firmness of the fruit. Potential postharvest effects of $\mathrm{CH}_{2} \mathrm{~N}_{2}$ and $\mathrm{CaNH}_{4} \mathrm{NO}_{3}$ on sweet cherry have not been reported. Expansion and further development of markets for California cherries necessitates a more conclusive understanding of the impact of $\mathrm{GA}_{3}, \mathrm{CH}_{2} \mathrm{~N}_{2}$, and $\mathrm{CaNH}_{4} \mathrm{NO}_{3}$ on postharvest fruit quality, especially when up to $12 \%$ losses have occurred at the retail and consumer level from quality-related problems (Ceponis and Butterfield, 1981). This study was undertaken to determine the effects of $\mathrm{GA}_{3}, \mathrm{CH}_{2} \mathrm{~N}_{2}$, and $\mathrm{CaNH}_{4} \mathrm{NO}_{3}$ on the quality attributes of 'Bing' sweet cherry fruits stored under three specific storage regimes typically required for marketing of sweet cherries.

\section{Materials and Methods}

Mature 'Bing' cherry trees of moderate crop load, grown on Maheleb rootstock within relatively large and uniform plantings of commercial cherries were selected from a separate orchard located on a loam-textured soil in the Central Valley of Calif. for each of the 3 years of study (1998, 1999, and 2000). Trees from within the orchard for each of the years were formed into a randomized complete-block design comprising four treatments replicated across six blocks. Label rates of $\mathrm{CH}_{2} \mathrm{~N}_{2}$ (Dormex, SKW Trostberg, Trostberg, Germany) at $7.8 \mathrm{~kg} \cdot \mathrm{ha}^{-1}$ a.i. in 935 $\mathrm{L}$ of water and $\mathrm{CaNH}_{4} \mathrm{NO}_{3}(9 \% \mathrm{Ca}$ and $17 \%$ N, w/w) (CAN17, Unocal Corp., El Segundo, Calif.) at $468 \mathrm{~L} \cdot \mathrm{ha}^{-1}$ of solution in $1400 \mathrm{~L}$ of water were applied during dormancy in midJanuary of all 3 years. A surfactant (Optima, Helena Chemical Co., Memphis, Tenn.) at 37 $\mathrm{L} \cdot \mathrm{ha}^{-1}$ was incorporated with the application of $\mathrm{CaNH}_{4} \mathrm{NO}_{3}$. Gibberellic acid (ProGibb 4\%, Valent USA Corp., Walnut Creek, Calif.) at 60 $\mathrm{g} \cdot \mathrm{ha}^{-1}$ a.i. in $1870 \mathrm{~L}$ of water was applied just prior to fruit straw color development in May of all 3 years. Untreated cherries represented the control treatment.

Harvest date for fruit of each treatment coincided with the main commercial harvest for such treated fruit, generally occurring when the majority of the cherries were at the red and mahogany stages of skin color development. Harvesting of $\mathrm{CH}_{2} \mathrm{~N}_{2}$-treated cherries occurred on 25, 31, and 18 May; $\mathrm{CaNH}_{4} \mathrm{NO}_{3}$-treated cherries on 4 and 7 June, and 21 May; controls 
on 8 and 8 June, and 23 May; and $\mathrm{GA}_{3}$-treated cherries on 9 and 9 June, and 29 May, for the years 1998, 1999, and 2000, respectively. At each harvest, proportionate samples of fruit from the upper and lower and inner and outer portions of the canopy for four distinctive skin color categories were obtained. Fruit color categories were salmon (1), red (3), mahogany (4), and dark mahogany (6), the numbers corresponding to color category chips (Centre Technique Interprofessional des Fruits et Legumes, Paris).

Fruit were segregated into four groups, three for storage, and one nonstorage group, with each group comprising 25 cherries of each color category per replicated block. Simulated storage regimes included an export air shipment (AIR), a domestic truck shipment (TRUCK), and a domestic truck shipment including retail storage (RETAIL). Export air shipment required fruit in cherry boxes to be fumigated at a commercial facility for $2 \mathrm{~h}$ with methyl bromide (Great Lakes Chemical Corp., Indianapolis) at $64 \mathrm{~g} \cdot \mathrm{m}^{-3}$ of air space. Fumigation and the subsequent holding period totaled $24 \mathrm{~h}$ and occurred at 12 to 18 ${ }^{\circ} \mathrm{C}$. Fruit were then transferred to $5{ }^{\circ} \mathrm{C}$ for 33 $\mathrm{h}$, then to $20{ }^{\circ} \mathrm{C}$ for $15 \mathrm{~h}$, all at $95 \%$ relative humidity (RH). TRUCK fruit were held at 2 ${ }^{\circ} \mathrm{C}$ for $5 \mathrm{~d}$, then $20{ }^{\circ} \mathrm{C}$ for $1 \mathrm{~d}$, all at $60 \% \mathrm{RH}$. The RETAIL protocol required fruit to be held at $2{ }^{\circ} \mathrm{C}$, then $7{ }^{\circ} \mathrm{C}$, each for $5 \mathrm{~d}$, then $20{ }^{\circ} \mathrm{C}$ for $1 \mathrm{~d}$, all at $60 \% \mathrm{RH}$. Nonstored fruit were held overnight at $0{ }^{\circ} \mathrm{C}$ and then warmed to 20 ${ }^{\circ} \mathrm{C}$ immediately prior to evaluation. With the exception of AIR fruit, stored cherries were treated with the fungicide Tebuconazole (Elite 45 DF, Bayer Corp., Kansas City, Mo.) at 148 $\mathrm{mg} \cdot \mathrm{L}^{-1}$, then blotted dry and held in open plastic bags. In 1999 and 2000, fruit were transferred into open mesh containers during the final holding period at $20^{\circ} \mathrm{C}$.

Cherries were evaluated shortly after harvest and after storage for specific damage symptoms. Fruit were considered surface pitted if the sum of pit diameters on a cherry exceeded $3 \mathrm{~mm}$ in diameter. Any visible fungal growth was scored as decay. Any visible wrinkling of the fruit surface was scored as shriveled. Cherries with over $30 \%$ surface stem discoloration were scored as suffering "brown stem." Nondestructive flesh firmness was measured by force/deformation in Newtons per millimeter $(\mathrm{N} / \mathrm{mm})$ and fruit diameter in mm (FirmTech1, BioWorks, Stillwater, Okla.) on each cherry. External skin hue color, measured by colorimetry (modelCR-300, Minolta, Ramsey, N.J.) in ${ }^{\circ}$ hue, was measured on both cheeks of each cherry. Percent SSC was determined by refractometry (Abbe model 10450, American Optical, Buffalo, N.Y.) and TA (malic acid equivalents) by automatic titration (PHM85 Precision, ABU80; Radiometer, Copenhagen, Denmark) in the juice of two 12cherry composite samples from each replicated block of each treatment. These variables were analyzed for the effects of year, treatment, storage regime, and skin color category by analysis of variance using Statistical Analysis System (SAS) software, version 6.2. Interactions between year, treatment, and storage regime were also tested.

\section{Results and Discussion}

Color. Cherry skin color (hue) was similar for treatment and year (Table 1) indicating that, overall, fruit were of comparable maturity between the four treatments and 3 years. Cherry selection using color chips resulted in small differences in color $\left(<1^{\circ}\right.$ hue) between treatments within years and storage regimes. Fruit skin color has generally been accepted as the most reliable maturity criterion for 'Bing' (Facteau et al., 1983; Proebsting and Mills, 1981) and, in general, most sweet cherries (Timm et al., 1995), and is often the basis for timing of commercial harvest. Therefore, contrasts between treatments and years within each of the remaining fruit quality parameters would, overall, result from effects other than the perceived fruit maturity based on skin color. Subjective partitioning of cherries into the four color categories at harvest reflected distinctive skin hue measurements with a large proportion of statistical variance associated with color category (Table 1). Relatively distinctive skin hue measurements also existed between the storage regimes. In addition, cherry skin color changed during storage, intensifying $3.3^{\circ}$ hue or almost one color category between nonstored and RETAIL stored fruit. This was consistent across years as evidenced from the nonsignificant interaction between year and storage regime.

Firmness. Firmness is an important quality attribute of cherry that has been reported to enhance storage potential, improve resistance to decay organisms and mechanical injury, and appeal to consumer preferences (Brown and Bourne, 1988). At comparable stages of maturity, $\mathrm{GA}_{3}$-treated fruit were firmer than control fruit (Table 1), concurring with findings from other studies (Facteau, 1982; Facteau and Rowe, 1979; Facteau et al., 1985; Looney and Lidster, 1980; Proebsting et al., 1973). Overall, $\mathrm{GA}_{3}$ - and $\mathrm{CH}_{2} \mathrm{~N}_{2}$-treated fruit averaged similar firmness, being $12 \%$ to $22 \%$ firmer than control fruit across the years. However, $\mathrm{CH}_{2} \mathrm{~N}_{2}$ fruit were slightly firmer than $\mathrm{GA}_{3}$ fruit in 1998 and 2000 (data not shown), both years of relatively firm cherries, yet $12 \%$ softer in 1999 , a year of comparably softer cherries (Table 1). In contrast, $\mathrm{GA}_{3}$ fruit was slightly firmer than $\mathrm{CH}_{2} \mathrm{~N}_{2}$ fruit for nonstored and AIR cherries, regimes comprised of firmer fruit, yet slightly softer for TRUCK cherries (Fig. 1). The $\mathrm{GA}_{3}$ cherries were also generally firmer than $\mathrm{CH}_{2} \mathrm{~N}_{2}$ cherries at the salmon- and red-colored stages, but not at the softer mahogany and dark mahogany stages of maturity (Fig. 1). Interactions of treatment with year and storage regime were significant, yet together reflect inconsistency with respect

Table 1. Fruit quality attributes of 'Bing' cherry between preharvest treatments, years, storage regimes, and fruit skin color categories.

\begin{tabular}{|c|c|c|c|c|c|c|c|c|c|}
\hline & $\begin{array}{l}\text { Skin color } \\
\left({ }^{\circ} \text { hue }\right)^{\mathrm{z}}\end{array}$ & $\begin{array}{c}\text { Firmness } \\
(\mathrm{N} / \mathrm{mm})\end{array}$ & $\begin{array}{l}\text { Diam } \\
(\mathrm{mm})\end{array}$ & $\begin{array}{l}\mathrm{SSC} \\
(\%)\end{array}$ & $\begin{array}{l}\text { TA } \\
(\%)\end{array}$ & $\begin{array}{c}\text { Pitting } \\
(\%)\end{array}$ & $\begin{array}{c}\text { Shrivel } \\
(\%)\end{array}$ & $\begin{array}{c}\text { Decay } \\
(\%)\end{array}$ & $\begin{array}{c}\text { Brown }^{y} \\
\text { stem }(\%)\end{array}$ \\
\hline \multicolumn{10}{|l|}{ Treatment $^{\mathrm{x}}$} \\
\hline $\mathrm{CH}_{2} \mathrm{~N}_{2}$ & 18.6 & $2.10 \mathrm{a}^{\mathrm{w}}$ & $26.5 \mathrm{a}$ & 16.8 & 0.83 & $5 \mathrm{bc}$ & $5 \mathrm{c}$ & 0.3 & $10 \mathrm{~b}$ \\
\hline $\mathrm{CaNH}_{4} \mathrm{NO}_{3}$ & 18.7 & $1.81 \mathrm{~b}$ & $25.7 \mathrm{~b}$ & 16.2 & 0.82 & $6 \mathrm{ab}$ & $18 \mathrm{a}$ & 0.5 & $6 c$ \\
\hline Control & 18.6 & $1.83 \mathrm{~b}$ & $25.6 \mathrm{~b}$ & 16.8 & 0.85 & $7 \mathrm{a}$ & $15 \mathrm{ab}$ & 0.3 & $7 \mathrm{c}$ \\
\hline $\mathrm{GA}_{3}$ & 19.0 & $2.13 \mathrm{a}$ & $25.5 \mathrm{~b}$ & 16.1 & 0.83 & $4 \mathrm{c}$ & $12 \mathrm{~b}$ & 0.1 & $14 \mathrm{a}$ \\
\hline \multicolumn{10}{|l|}{ Year } \\
\hline 2000 & 18.8 & $2.02 \mathrm{~b}$ & $24.3 \mathrm{~b}$ & $19.3 \mathrm{a}$ & $0.88 \mathrm{a}$ & $3 \mathrm{~b}$ & $27 \mathrm{a}$ & $0.7 \mathrm{a}$ & $13 \mathrm{a}$ \\
\hline 1999 & 18.5 & $1.76 \mathrm{c}$ & $24.0 \mathrm{~b}$ & $15.6 \mathrm{~b}$ & $0.84 \mathrm{a}$ & $10 \mathrm{a}$ & $7 \mathrm{~b}$ & $0.0 \mathrm{~b}$ & $14 \mathrm{a}$ \\
\hline 1998 & 18.8 & $2.12 \mathrm{a}$ & $29.0 \mathrm{a}$ & $15.0 \mathrm{~b}$ & $0.78 \mathrm{~b}$ & $4 b$ & $2 \mathrm{c}$ & $0.1 \mathrm{~b}$ & $1 \mathrm{~b}$ \\
\hline \multicolumn{10}{|l|}{ Storage $^{v}$} \\
\hline Nonstored & $20.2 \mathrm{a}$ & $2.12 \mathrm{a}$ & $26.0 \mathrm{a}$ & $16.2 \mathrm{c}$ & $0.88 \mathrm{a}$ & $2 \mathrm{c}$ & $0 \mathrm{~d}$ & $0.0 \mathrm{c}$ & $0 \mathrm{~d}$ \\
\hline AIR & $19.4 \mathrm{~b}$ & $1.99 \mathrm{~b}$ & $25.8 \mathrm{~b}$ & $16.8 \mathrm{a}$ & $0.87 \mathrm{~b}$ & $5 \mathrm{~b}$ & $8 \mathrm{c}$ & $0.4 \mathrm{ab}$ & $18 \mathrm{a}$ \\
\hline TRUCK & $18.5 \mathrm{c}$ & $1.86 \mathrm{c}$ & $25.7 \mathrm{~b}$ & $16.5 \mathrm{~b}$ & $0.80 \mathrm{c}$ & $8 \mathrm{a}$ & $15 \mathrm{~b}$ & $0.2 \mathrm{bc}$ & $6 c$ \\
\hline RETAIL & $16.9 \mathrm{~d}$ & $1.88 \mathrm{c}$ & $25.8 \mathrm{~b}$ & $16.4 \mathrm{~b}$ & $0.77 \mathrm{~d}$ & $9 \mathrm{a}$ & $25 \mathrm{a}$ & $0.5 \mathrm{a}$ & $12 \mathrm{~b}$ \\
\hline \multicolumn{10}{|l|}{ Color category } \\
\hline Salmon & $25.7 \mathrm{a}$ & $2.17 \mathrm{a}$ & $25.4 \mathrm{~d}$ & $13.0 \mathrm{~d}$ & $0.85 \mathrm{a}$ & $4 c$ & $11 \mathrm{bc}$ & $0 \mathrm{~b}$ & $5 \mathrm{~d}$ \\
\hline Red & $21.0 \mathrm{~b}$ & $1.94 \mathrm{~b}$ & $25.6 \mathrm{c}$ & $14.8 \mathrm{c}$ & $0.81 \mathrm{~b}$ & $7 \mathrm{a}$ & $10 \mathrm{c}$ & $0.1 \mathrm{~b}$ & $7 \mathrm{c}$ \\
\hline Mahogany & $15.8 \mathrm{c}$ & $1.87 \mathrm{c}$ & $26.0 \mathrm{~b}$ & $17.7 \mathrm{~b}$ & $0.81 \mathrm{~b}$ & $6 \mathrm{~b}$ & $12 \mathrm{~b}$ & $0.2 \mathrm{~b}$ & $11 \mathrm{~b}$ \\
\hline Dk mahogany & $12.6 \mathrm{~d}$ & $1.87 \mathrm{c}$ & $26.2 \mathrm{a}$ & $20.6 \mathrm{a}$ & $0.85 \mathrm{a}$ & $5 \mathrm{bc}$ & $15 \mathrm{a}$ & $0.8 \mathrm{a}$ & $14 \mathrm{a}$ \\
\hline \multicolumn{10}{|l|}{ Source $^{u}$} \\
\hline Treatment (T) & $0^{\mathrm{Ns}}$ & $11^{* * * *}$ & $2^{* * * *}$ & $0^{\mathrm{Ns}}$ & $0^{\mathrm{NS}}$ & $1^{* *}$ & $1^{* * *}$ & $0^{\mathrm{Ns}}$ & $2^{* * *}$ \\
\hline Year (Y) & $0^{\mathrm{Ns}}$ & $13^{* * * *}$ & $58^{* * *}$ & $24^{* * * *}$ & $2^{* * *}$ & $17^{* * *}$ & $16^{* * * *}$ & $4^{* * * *}$ & $17^{* * *}$ \\
\hline Storage (S) & $6^{* * *}$ & $4^{* * * *}$ & $1^{* * * *}$ & $1^{* * * *}$ & $11^{* * * *}$ & $15^{* * *}$ & $21^{* * * *}$ & $1^{* * * *}$ & $16^{* * *}$ \\
\hline Color category & y $81^{* * * *}$ & $7^{* * *}$ & $4^{* * *}$ & $54^{* * * *}$ & $3^{* * *}$ & $1^{* * * *}$ & $3^{* * *}$ & $2^{* * *}$ & $4^{* * *}$ \\
\hline $\mathrm{T} \times \mathrm{Y}$ & $2^{* * *}$ & $1^{* * *}$ & $8^{* * *}$ & $8^{* * *}$ & $38^{* * *}$ & $2^{* *}$ & $10^{* * *}$ & $0^{\mathrm{Ns}}$ & $1^{* * *}$ \\
\hline $\mathrm{T} \times \mathrm{S}$ & $1^{* * *}$ & $1^{* * *}$ & $0^{\mathrm{NS}}$ & $0^{\mathrm{NS}}$ & $1^{* * *}$ & $1^{* * *}$ & $1^{* * *}$ & $1^{*}$ & $1^{* * *}$ \\
\hline $\mathrm{Y} \times \mathrm{S}$ & $0^{\mathrm{Ns}}$ & $3^{* * *}$ & $1^{* * * *}$ & $1^{* * * *}$ & $6^{* * * *}$ & $5^{* * *}$ & $11^{* * * *}$ & $1^{* * * *}$ & $16^{* * * *}$ \\
\hline
\end{tabular}

${ }^{\mathrm{z}}$ Angle attributed to colors classed as red $\left(0^{\circ}\right)$, yellow $\left(90^{\circ}\right)$, green $\left(180^{\circ}\right)$, blue $\left(270^{\circ}\right)$ or an intermediate between any adjacent pair of these colors.

yProportion of fruit with incidence of injury. Data was angular transformed prior to analysis of variance. ${ }^{x}$ Hydrogen cyanamide $\left(\mathrm{CH}_{2} \mathrm{~N}_{2}\right)$, calcium ammonium nitrate $\left(\mathrm{CaNH}_{4} \mathrm{NO}_{3}\right)$, gibberellic acid $\left(\mathrm{GA}_{3}\right)$.

"Mean separation within columns and factors by least significant difference, $P \leq 0.05$, whereby means associated with different letters signify significant differences.

${ }^{\vee}$ Export air shipment (AIR, 3 d storage), domestic truck shipment (TRUCK, 6 d storage), domestic truck shipment plus retail (RETAIL, $11 \mathrm{~d}$ storage).

"Numerical values are the estimated proportion $(\%)$ of variance associated with each source. Variance associated with error and various interactions not shown.

ns, *,**,*** Nonsignificant or significant at $P \leq 0.05,0.01$, or 0.001 , respectively. 
to either $\mathrm{GA}_{3}$ or $\mathrm{CH}_{2} \mathrm{~N}_{2}$ being more effective based on general fruit firmness, and are more likely responses to environmental or other effects. Cherries treated with $\mathrm{CaNH}_{4} \mathrm{NO}_{3}$ were similar in firmness to control fruit during all years, storage regimes, and color categories. Overall, fruit softened during storage, but not during simulated retail storage (Table 1). However, the rate of softening in mahogany and dark mahogany fruit was less than that for salmon-and red-colored cherries (Fig. 1). There was no difference in overall firmness between mahogany and dark mahogany fruit.

Size. Fruit size is of particular interest to cherry producers because of its influence on marketing. The $\mathrm{GA}_{3}$ treatment did not increase fruit size, in agreement with Looney and Lidster (1980), but in contrast to the findings of Facteau et al. (1985) and Facteau and Rowe (1979). Hydrogen cyanamide-treated cherries were, on average, almost $4 \%$ larger in diameter than fruit of the remaining treatments (Table 1).
Although differences were negligible in 1999 , $\mathrm{CH}_{2} \mathrm{~N}_{2}$ treatment resulted in cherries that were $7 \%$ wider in 1998 . However, the effect of year was greater than that of treatment as overall cherry size in 1998 was at least $20 \%$ larger than in 1999 and 2000; a large proportion of statistical variance was attributed to year differences (Table 1). Non-stored fruit were larger than fruit of the AIR, TRUCK, and RETAIL storage regimes. Water loss during storage most likely caused contraction of fruit volume, although why differences between AIR, TRUCK, and RETAIL regimes did not occur is uncertain, particularly as AIR fruit were stored for only $3 \mathrm{~d}$ and at high RH. Nonetheless, small yet distinctive loss of weight has been reported in cherries between cold storage periods of 2 , 4, and 6 weeks, although RH was not reported (Drake and Fellman, 1987). As expected, more mature fruit were larger than less mature fruit, consistent with findings of Drake and Fellman (1987) in 'Rainier' cherries.

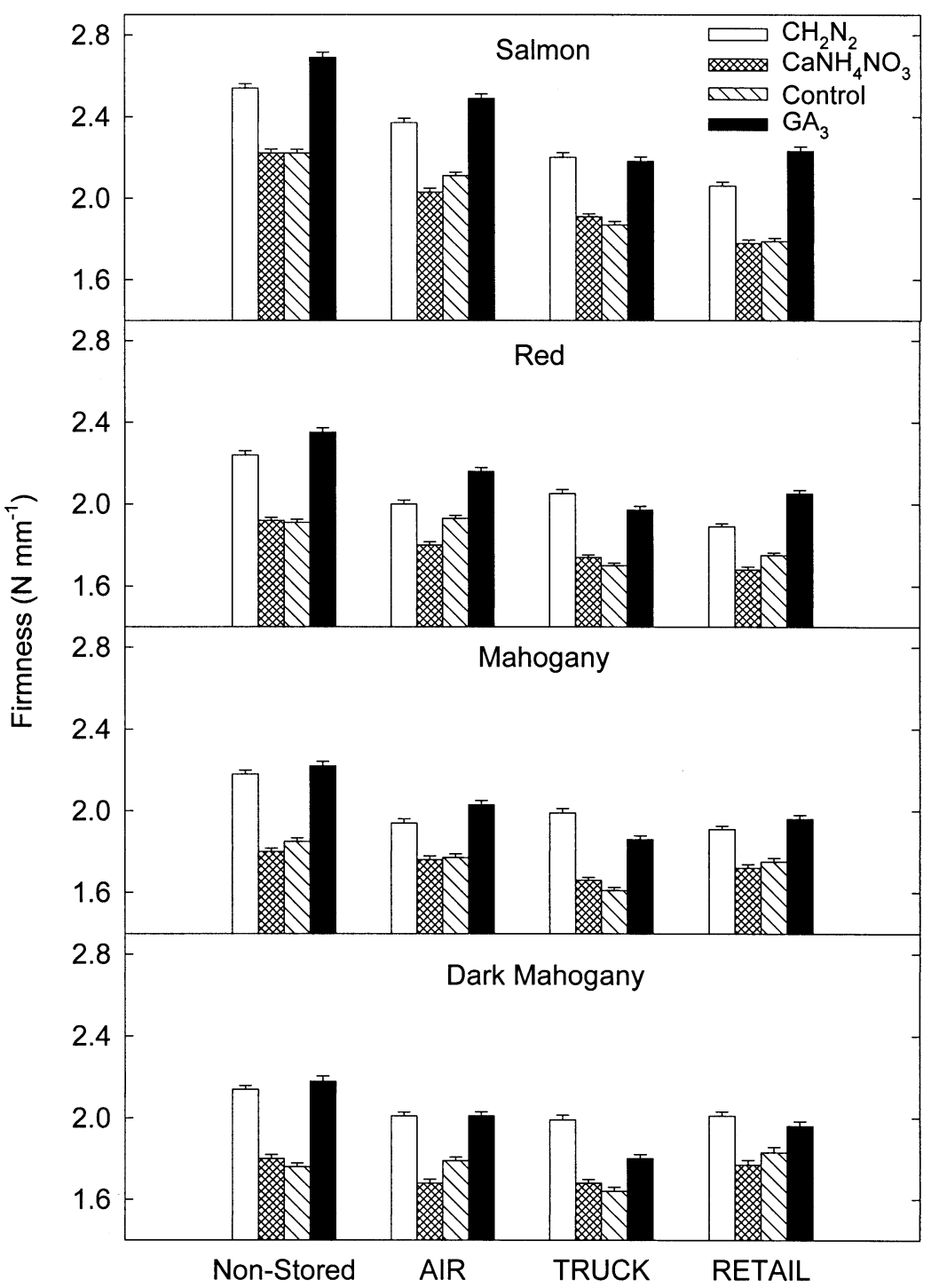

Fig. 1. Firmness of 'Bing' cherries non-treated (control) or preharvest treated with hydrogen cyanamide $\left(\mathrm{CH}_{2} \mathrm{~N}_{2}\right)$, calcium ammonium nitrate $\left(\mathrm{CaNH}_{4} \mathrm{NO}_{3}\right)$, or gibberellic acid $\left(\mathrm{GA}_{3}\right)$ in nonstored or stored fruit held for $3 \mathrm{~d}$ [export air shipment, (AIR)], $6 \mathrm{~d}$ [domestic truck shipment (TRUCK)], or $11 \mathrm{~d}$ [domestic truck shipment plus retail (RETAIL)]. Firmness within treatments, storage regimes, and fruit maturities are averaged across 3 years. Vertical bars represent SE.
Soluble solids and titratable acidity. Overall, SSC and TA did not vary with respect to treatment, but did with respect to year, whereby SSC was relatively high in 2000 and TA was low in 1998. Inconsistent differences existed between treatments within years for SSC, and particularly for TA; a substantial proportion of variance occurred from treatment interactions with year (Table 1). The effect of treatment on these parameters remains uncertain, as possible effects were masked by a more dominant unidentified influence. The inconsistent effects of $\mathrm{GA}_{3}$ on SSC and TA found in other studies support this conclusion(Facteau, 1982; Looney and Lidster, 1980; Proebsting et al., 1973). Iezzoni (1986) also attributed an unidentified factor as causing SSC in sour cherry to vary significantly between years but not between cultivars, yet interacting strongly between both. The author reported this inconsistency to be unique to SSC, although TA was not measured. In our study, a relatively large proportion of variance was associated with color category and storage regime for SSC and TA, respectively (Table 1). In each case, SSC increased as fruit matured and TA decreased during storage. However, SSC during storage and TA across fruit color categories did not reflect such consistent responses. Despite being statistically significant, both exhibited a small variance component for storage regime and color category, respectively.

Pitting. Surface pitting detracts from the appearance of cherry fruits, reflecting irregular shaped sunken areas. Cherries treated with $\mathrm{GA}_{3}$ were less susceptible to pitting, but only in 1999, a year of relatively severe pitting (Table 1, Fig. 2). Other studies similarly indicated that this effect of $\mathrm{GA}_{3}$ on surface pitting was more dramatic in years with increased incidence of the injury (Facteau and Rowe, 1979; Looney and Lidster, 1980). Facteau (1982b) found an association between firmer cherries and reduced surface pitting in 'Bing' and 'Lambert' and cited studies similarly showing an association with $\mathrm{GA}_{3}$-firmed cherries, but doubted that firmness alone was responsible for less pitting. Looney and Lidster (1980) likewise concluded that reduced surface pitting in cherry from $\mathrm{GA}_{3}$ treatment was due to some effect other than increased fruit firmness. Our study supports this opinion. While $\mathrm{GA}_{3}$-treated cherries had reduced pitting in 1999, this was not evident in $\mathrm{CH}_{2} \mathrm{~N}_{2}$-treated fruit (Fig. 2), which were also considerably firmer than control and $\mathrm{CaNH}_{4} \mathrm{NO}_{3}$ cherries. Although some pitting was evident at harvest, the majority of pitting developed during storage, being equally severe for TRUCK and RETAIL fruit (Table 1). Despite differences in fruit susceptibility, pitting was marginal between the color categories relative to year and storage regime, as indicated by the estimated proportions of variance (Table 1).

Decay and shrivel. Decay has been reported to be the major contributor to sweet cherry losses at market (Ceponis and Butterfield, 1981), but fruit subjected to our simulated shipping and retail storage regime had a relatively low incidence of decay (Table 1). There were no differences in decay between 


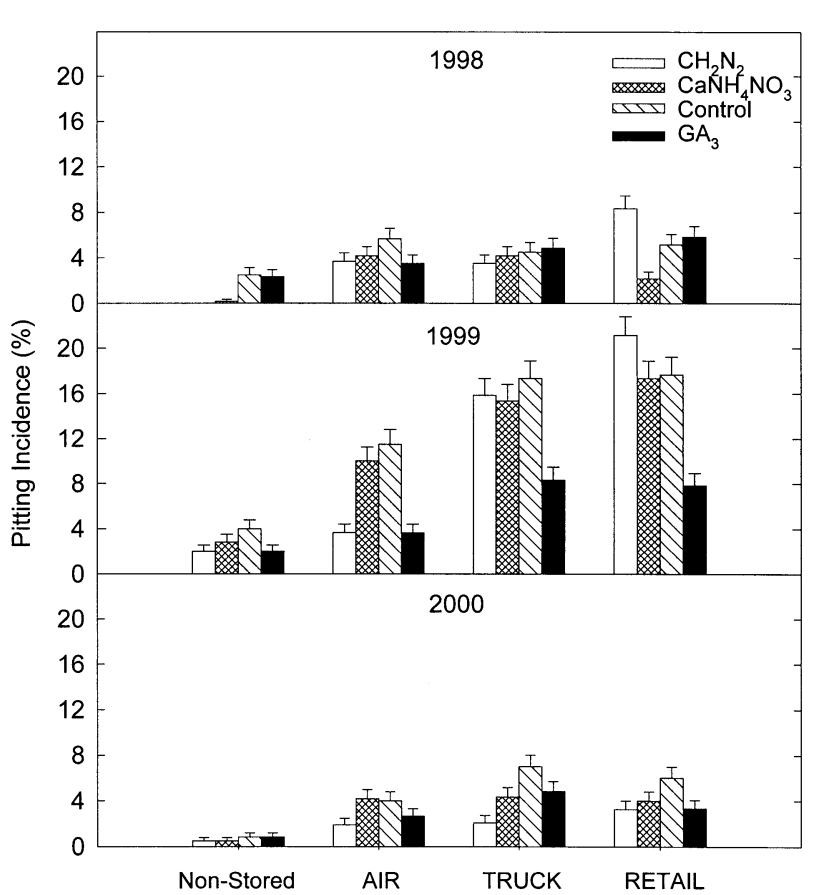

Fig. 2. Proportion of surface pitted 'Bing' cherries non-treated (control) or preharvest treated with hydrogen cyanamide $\left(\mathrm{CH}_{2} \mathrm{~N}_{2}\right)$, calcium ammonium nitrate $\left(\mathrm{CaNH}_{4} \mathrm{NO}_{3}\right)$, or gibberellic acid $\left(\mathrm{GA}_{3}\right)$ in nonstored or stored fruit held for $3 \mathrm{~d}$ [export air shipment, (AIR)], $6 \mathrm{~d}$ [domestic truck shipment (TRUCK)], or $11 \mathrm{~d}$ [domestic truck shipment plus retail (RETAIL)]. Pitting incidence within treatment, storage regime, and year was averaged across fruit maturities. Vertical bars represent SE.

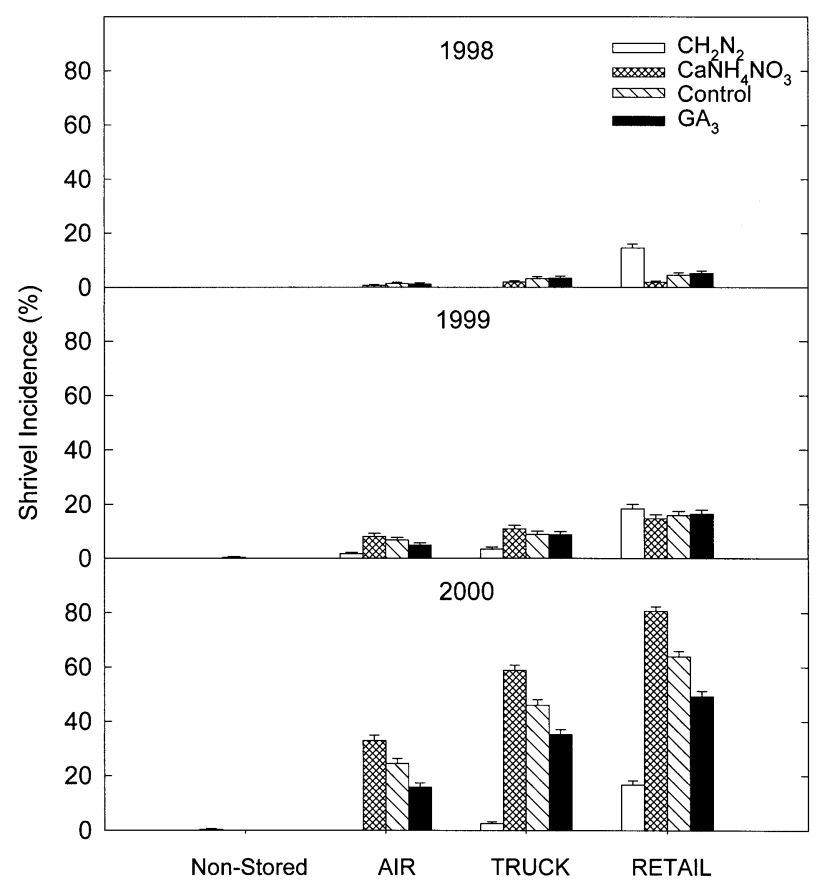

Fig. 3. Proportion of shriveled 'Bing' cherries nontreated (control) or preharvest treated with hydrogen cyanamide $\left(\mathrm{CH}_{2} \mathrm{~N}_{2}\right)$, calcium ammonium nitrate $\left(\mathrm{CaNH}_{4} \mathrm{NO}_{3}\right)$, or gibberellic acid $\left(\mathrm{GA}_{3}\right)$ in nonstored or stored fruit held for $3 \mathrm{~d}$ [export air shipment, (AIR)], $6 \mathrm{~d}$ [domestic truck shipment (TRUCK)], or $11 \mathrm{~d}$ [domestic truck shipment plus retail (RETAIL)]. Shrivel incidence within treatment, storage regime, and year was averaged across fruit maturities. Vertical bars represent SE. fruit of the various treatments. Decay incidence was higher in 2000, largely in dark mahogany fruit. However, fruit shrivel was more prevalent, also predominantly occurring in 2000, where $\mathrm{CH}_{2} \mathrm{~N}_{2}$-treated cherries suffered considerably less shrivel compared to the remaining treatments (Table 1, Fig. 3). The $\mathrm{CaNH}_{4} \mathrm{NO}_{3}$-treated fruit had a particularly high percentage with shrivel in 2000 , yet differences between treatments for shrivel in 1998 and 1999 were negligible. Temperature during harvest likely contributed to this occurrence in 2000. Average orchard air temperature during the harvest of $\mathrm{CaNH}_{4} \mathrm{NO}_{3}$ and control fruit was 27 and $25{ }^{\circ} \mathrm{C}$, respectively. For $\mathrm{CH}_{2} \mathrm{~N}_{2}$ and $\mathrm{GA}_{3}$ fruit, average orchard temperature was $18^{\circ} \mathrm{C}$, although the preharvest $\mathrm{GA}_{3}$ fruit were also previously exposed to the high temperatures experienced by $\mathrm{CaNH}_{4} \mathrm{NO}_{3}$ and control fruit, possibly contributing to their increased shrivel compared to $\mathrm{CH}_{2} \mathrm{~N}_{2}$ cherries. Nonetheless, signs of shrivel were negligible during harvest and subsequently developed in storage, becoming progressively worse during storage (Table 1, Fig. 3).

Stem browning. Stem browning typically develops during cherry storage, and is also associated with the methyl bromide fumigation required for insect disinfestation by certain export markets. The incidence of brown stem was negligible in non-stored fruit, but increased in TRUCK and RETAIL fruit, which were stored for 6 and $11 \mathrm{~d}$, respectively (Table 1). However, the greatest incidence of brown stem occurred in AIR fruit, which were fumigated and stored for only $3 \mathrm{~d}$. Overall, $\mathrm{GA}_{3}$ fruit appeared more susceptible to stem browning, although $\mathrm{CH}_{2} \mathrm{~N}_{2}$ fruit were occasionally very susceptible-yet not consistently so between storage regimes and years (Table 1, Fig. 4). Differences in susceptibility of fruit between

years also featured strongly. On average the disorder occurred in $1 \%$ of fruit in 1998 and in $14 \%$ and $13 \%$ of fruit in 1999 and 2000, respectively, possibly due to higher humidity from holding the fruit at $20{ }^{\circ} \mathrm{C}$ in open plastic

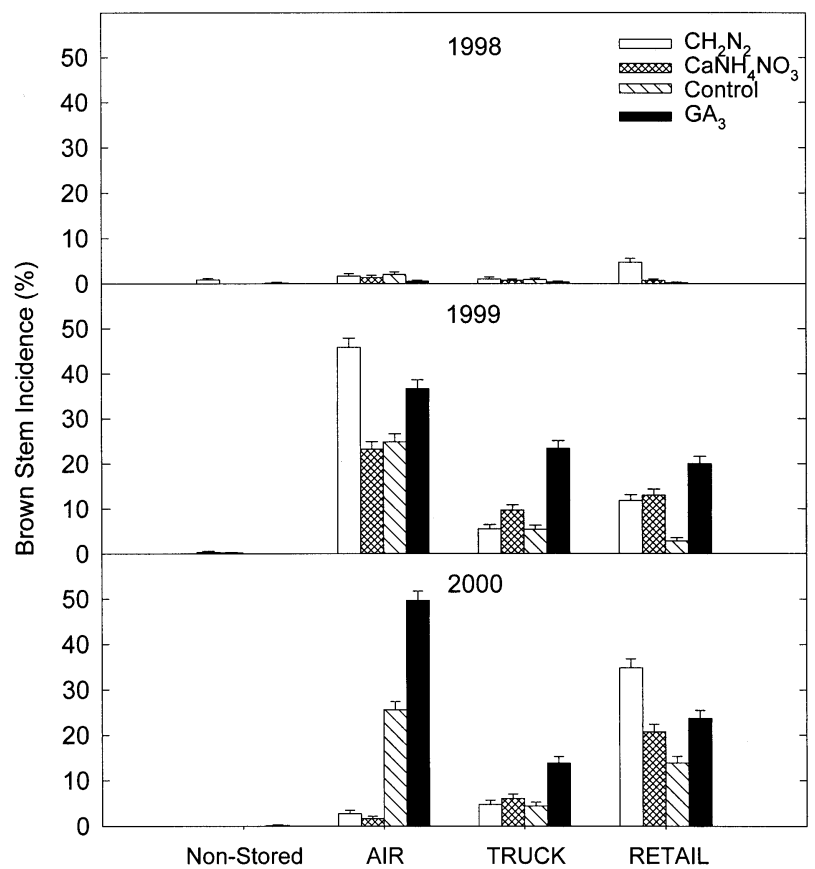

Fig. 4. Proportion of brown stemmed 'Bing' cherries non-treated (control) or preharvest treated with hydrogen cyanamide $\left(\mathrm{CH}_{2} \mathrm{~N}_{2}\right)$, calcium ammonium nitrate $\left(\mathrm{CaNH}_{4} \mathrm{NO}_{3}\right)$, or gibberellic acid $\left(\mathrm{GA}_{3}\right)$ in non-stored or stored fruit held for $3 \mathrm{~d}$ [export air shipment, (AIR)], $6 \mathrm{~d}$ [domestic truck shipment (TRUCK)], or $11 \mathrm{~d}$ [domestic truck shipment plus retail (RETAIL)]. Brown stem incidence within treatment, storage regime, and year was averaged across fruit maturities. Vertical bars represent SE. 
bags in 1998 vs. open mesh containers in 1999 and 2000. Differences in brown stem susceptibility also existed between fruit maturity, being more severe in darker colored, more mature cherries.

Other factors affecting quality. With the exception of firmness, one of the most important quality indices of fresh market sweet cherries, the effects of the preharvest treatments on postharvest fruit quality were either nonexistent or small in comparison to differences between years. The extent to which environmental conditions, management practices, or other factors caused such yearly differences remains uncertain. An extensive study of 'Bing' revealed that SSC, fruit weight, and firmness at a standard skin color varied considerably across 9 years of evaluations, often without relationship to crop load (Proebsting and Mills, 1981). Yet Facteau (1982b) speculated that crop load, tree vigor, and environmental conditions were major factors affecting fruit firmness.

During our study, environmental conditions prior to and during harvest varied considerably between years, possibly influencing overall fruit firmness and other quality indices. Mean and maximum monthly temperatures for the 3 months prior to harvest were 1 to $2{ }^{\circ} \mathrm{C}$ higher in 2000 as compared to 1999 , and 2 to $3{ }^{\circ} \mathrm{C}$ higher in 1999 as compared to 1998 . In addition, air temperature during harvest of $\mathrm{CH}_{2} \mathrm{~N}_{2}, \mathrm{CaNH}_{4} \mathrm{NO}_{3}$, and control fruit was 5, 10 , and $10{ }^{\circ} \mathrm{C}$ higher, respectively, in 2000 than in 1999 and 1998. In spite of such inconsistency in air temperature and the relatively large proportion of statistical variance associated with year for fruit firmness, $\mathrm{CH}_{2} \mathrm{~N}_{2}$ and $\mathrm{GA}_{3}$ cherries were consistently firmer than $\mathrm{CaNH}_{4} \mathrm{NO}_{3}$ and control fruit, which further attests to the influence of these compounds on fruit firmness. Furthermore, fruit treated with $\mathrm{CH}_{2} \mathrm{~N}_{2}$ and $\mathrm{GA}_{3}$ also maintained their higher firmness during storage.

\section{Conclusions}

In general, $\mathrm{CH}_{2} \mathrm{~N}_{2}$ and $\mathrm{GA}_{3}$ appeared beneficial in terms of enhancing postharvest fruit quality, while not in the least contributing to losses in quality for the parameters evaluated in this study. The exception was for brown stem disorder, where $\mathrm{CH}_{2} \mathrm{~N}_{2}$ and $\mathrm{GA}_{3}$ appeared to augment this condition in years where cherries were particularly susceptible. The $\mathrm{CaNH}_{4} \mathrm{NO}_{3}$ treatment had little, if any, impact on postharvest quality of 'Bing' cherries. Although shrivel was higher in $\mathrm{CaNH}_{4} \mathrm{NO}_{3}$ fruit, this only occurred in 2000, and was most likely in response to relatively high air temperatures during the harvest of this treatment in 2000.

\section{Literature Cited}

Brown, S.K. and M.C. Bourne. 1988. Assessment of components of fruit firmness in selected sweet cherry genotypes. HortScience 23:902-904.

Ceponis, M.J. and J.E. Butterfield. 1981. Cull losses in western sweet cherries at retail and consumer levels in metropolitan New York. HortScience 16:324-326.

Drake, S.R. and J.K. Fellman. 1987. Indicators of maturity and storage quality of 'Rainier' sweet cherry. HortScience 22:283-285.

Facteau, T.J. 1982a. Levels of pectic substances and calcium in gibberellic acid-treated sweet cherry fruit. J. Amer. Soc. Hort. Sci. 107:148-151.

Facteau, T.J. 1982b. Relationship of soluble solids, alcohol-insoluble solids, fruit calcium, and pectin levels to firmness and surface pitting in 'Lambert' and 'Bing' sweet cherry fruit. J. Amer. Soc. Hort. Sci. 107:151-154.

Facteau, T.J., N.E. Chestnut, and K.E. Rowe. 1983.
Relationship between fruit weight, firmness, and leaf/fruit ratio in Lambert and Bing sweet cherries. Can. J. Plant Sci. 63:763-765.

Facteau, T.J. and K.E. Rowe. 1979. Factors associated with surface pitting of sweet cherry. J. Amer. Soc. Hort. Sci. 104:706-710.

Facteau, T.J., K.E. Rowe, and N.E. Chestnut. 1985. Firmness of sweet cherry fruit following multiple applications of gibberellic acid. J. Amer. Soc. Hort. Sci. 110:775-777.

Iezzoni, A.F. 1986. Variance components and sampling procedures for fruit size and quality in sour cherry. HortScience 21:1040-1042.

Looney, N.E. and P.D. Lidster. 1980. Some growth regulator effects on fruit quality, mesocarp composition, and susceptibility to postharvest surface marking of sweet cherries. J. Amer. Soc. Hort. Sci. 105:130-134.

Proebsting, E.L. and H.H. Mills. 1981. Effects of season and crop load on maturity characteristics of 'Bing' cherry. J. Amer. Soc. Hort. Sci. 106: 144-146.

Proebsting, E.L., G.H. Carter, and H.H. Mills. 1973. Quality improvement in canned 'Rainier' cherries (P. avium L.) with gibberellic acid. J. Amer. Soc. Hort. Sci. 98:334-336.

Timm, E.J., D.E. Guyer, G.K. Brown, and N.L. Schulte. 1995. Michigan sweet cherry color measurements and prototype color chip development. Appl. Eng. Agr. 11:403-407.

Weis, K.G., S.M. Southwick, J.T. Yeager, M.E. Rupert, and W.W. Coates. 1998. Control of dormancy and budbreak in sweet cherry (Prunus avium L.) cv. 'Bing' with surfactant + calcium ammonium nitrate and hydrogen cyanamide. HortScience 33:514. (Abstr.)

Weis, K.G., S.M. Southwick, J.T. Yeager, M.E. Rupert, R.E. Moran, J.A. Grant, and W.W. Coates. 1999. Overcoming dormancy, advancing budbreak, and advancing fruit maturity in 'Bing' sweet cherry (Prunus avium L.): Surfactants/ dormant oils + calcium ammonium nitrate or hydrogen cyanamide. HortScience 34:525. (Abstr.) 